\title{
Economic impacts of Brexit to EU27 and UK
}

\author{
Article history: \\ Received: 12 January 2018 \\ Sent for revision: 9 February 2018 \\ Received in revised form: 29 May 2018 \\ Accepted: 29 May 2018 \\ Available online: 29 June 2018
}

\begin{abstract}
Assessment on economic consequences of Brexit to 27 countries members of European Union and to United Kingdom are researched in this paper. The process is current and challenging because some of the negotiating positions are still ongoing. Relevant economic parameters are calculated, analyzed and discussed, as well as spectrum from positive to negative scenarios of United Kingdom withdraw from European Union. Correlation coefficients are calculated and statistical analyses as temporal functions are conducted for gross domestic product of United Kingdom, compared to gross domestic product of European Union with and without United Kingdom. Aspect of trade, import, export, impact on gross domestic product and financial industry are considered with the goal to predict possible economic future for both sides of negotiation.
\end{abstract}

Keywords: Economy, Brexit, EU27, UK, GDP.

\section{Ekonomski uticaji Bregzit-a na EU27 i na UK}

Apstrakt: $U$ ovom radu je istražena procena ekonomskih posledica Bregzita na 27 zemalja članica Evropske Unije i Ujedinjeno Kraljevstvo. Proces je aktuelan i izazovan, jer su neke od pregovaračkih pozicija još uvek u toku. Relevantni ekonomski parametri se izračunavaju, analiziraju i diskutuju, kao $i$ spektar od pozitivnih do negativnih scenarija povlačenja Ujedinjenog Kraljevstva iz Evropske Unije. Koeficijenti korelacije su sračunati i urađene statističke analize kao vremenske funkcije za bruto društveni proizvod

\footnotetext{
${ }^{1}$ University Metropolitan, Faculty of Economics, Finance and Administration, Belgrade, Serbia, marko.stevovic96@gmail.com
} 
Ujedinjenog Kraljevstva, u poređenju sa bruto društvenim proizvodom Evropske Unije sa $i$ bez Ujedinjenog Kraljevstva. Razmatraju se aspekt trgovine, uvoza, izvoza, uticaja na bruto društveni proizvod $i$ finansijsku industriju sa ciljem da se predvidi moguća ekonomska budućnost za obe strane pregovora.

Ključne reči: Ekonomija, Bregzit, EU27, UK, BDP.

\section{Introduction}

The decision by the United Kingdom (UK) to abandon the European Union (EU) represents an unexpected and unprecedented event of EU practice. The lack of similar experiences as well as the unexpected decision to abandon the EU is an additional aggravating circumstance for a proper Brexit influence on the economic parameters of both the UK and the EU.There will certainly be changes in economic agreements that facilitated trade and economic cooperation within the EU while the UKwas a member of it. There will be certain changes to these agreements in terms of reducing trade relief. The process is complex, time-consuming and requires the engagement of multidisciplinary teams of experts, lawyers, politicians, economists. There are a number of options for how the UK's withdrawal from the EU can be completed. The final impacts of Brexit on the EU27 will largely be determined by negotiations that take place at the time of writing this paper. Although, the conducted research is current and challenging because it is based on a series of negotiating positions that are ongoing and/or still need to be started, undisputed facts about the effects of Brexit in economic terms can still be formulated in the following way (i.e. at this stage of research it is possible to adopt the following hypotheses):

- UKIt will certainly have negative economic consequences on both sides of the negotiation and

- Each party in the negotiations will strive to maximally protect their own interests.

There is no need to reject in advance either the assumption that the degree of protection of its own economic inertia of both sides will not be rationally based on economic principles but that each party will try to prove the correctness of their own political decision with the willingness to have a certain economic losses. That is, it is possible to include the assumption that EU withdrawal negotiations can be guided and completed in a way that will not minimize economic damage, but that economic effects will be optimized in the context of other goals. In this respect it is possible to conclude that economic interests will not be of crucial importance when final decisions are made on the 
formulation of an EU withdrawal agreement by either the UK or one of the negotiating parties.

It must also be kept in mind that it is not possible to predict all the economic consequences of the agreement on leaving the EU by the UK, as it was not possible to predict all consequences of the refugee crisis, Stevović and Crnobrnja (2015). The dynamics of global economic relations can at some point relate to individual solutions that are mutually accepted and bring benefits and/or damage to one or the other side. Brexit is a complex phenomenon. On the same time it has a political, Stevovic (2018a), security and other aspect to, Stevovic (2018b).

The significance of Brexit is confirmed by a large number of scientific papers, academic researches, conferences dedicated to this topic as well as statements by independent economic experts. The fact that new research and opinions on the topic of Brexit constantly appear to indicate that it is not sufficiently explored and that it has not been sufficiently explained and opens up the possibility for further research.

The subject of this paper is to explore objective consequences on the economic aspect of the UK and EU27 relations in the light of Brexit. It is based on rational assumptions that each side seeks to maximize their own benefit or to minimize their own damage. Bearing in mind that the UK has made a decision to leave the EU, it is a rational assumption that the decision is made with the introduction of greater benefits for the UK. By contrast, the $\mathrm{EU}$, which is not the initiator of this UK decision, should, on the assumption, minimize the damage caused by Brexit. Observed from the perspective of the above logic, the positions of the negotiating parties are defined. However, objective analysis requires identification, detailed research and analysis of all economic factors relevant to the realistic assessment of Brexit's influence on the economies of the UK and the EU.

\section{Research subject}

The subject of this paper is the impact of the UK's withdrawal from the EU on outsourced economies.

The research is based on following background:

- existing officiel data from eurostat $w^{2} b^{2}$, its correlation functions and statistical analysis;

\footnotetext{
${ }^{2}$ http://http://ec.europa.eu/eurostat/web/nationalaccounts/data/database?p_p_id=NavTreeportletprod_WAR_NavTreeportletprod_INST ANCE_HxOU2oGtTuFV\&p_p_lifecycle $=0 \& p \_p \_s t a t e=$ normal $\& p \_p \_$mode $=v i e w \& p \_p \_c$ ol_id=column-2\&p_p_col_count=3
} 
- existing documents describing the economic indicators of both sides ( UK and EU;

- scientific and professional papers dealing with the problem of Brexit from the economic aspect;

- statements by independent economic experts on Brexit and

- Statements by EU officials on the economic implications of Brexit.

To this end, research and evaluation of the existing economic relations between the UK and the EU was first conducted in research, and selection of relevant documents and literature describing the existing relations and results of the two economies (economy of EU and economy of UK) within the economic system.

Research, evaluation and analysis of methodologies that can be used for economic analysis of Brexit's influence on economic relations between the UK and the EU are done in addition to Brexit's analysis. The assessment of economic participation of gross domestic product (GDP) of UK in GDP of the EU is also analyzed dynamically in the period from 2006 to 2017. The correlation functions are researched.

Based on conducted economic research studies and methodologies that can be applied to economic relations, it was made their choice and analysis of possible economic scenarios on their mutual influence on the economies of the UK and the EU was completed upon completion of the negotiation process.

\section{Methodology}

The research methodology is based on a detailed analysis of economic parameters contained in available documents, evaluation and selection of facts contained in documents and papers that are relevant for a reliable conclusion on the economic implications of Brexit for both sides in the process of decompiling as well as on statements by EU and UK officials, which may have implications on both sides of the process.

The prevailing documents were found in a detailed study of the IMCO Committee, which produced an overview of all academic research studies based on EU and World Bank projections on models used by the EU in other bilateral relations.

The methodological holistic approach as per Castro, Kellison, Boyd, and Kopak (2010) has been applied, which includes methods of induction and deduction, analysis and synthesis as well as analogy according to Sarkar (2007). 
The author also applied statistical analises and method of comparison for the mean and total value of the GDP of EU, based on the official input data ${ }^{1}$. Methodology for the assessment of economic participation of UK GDP in EU GDP includes the statistical processing of the following GDP parameters for the period from 2006 to 2017:

- Mean GDP with and without UK and

- Total value of GDP with and without UK.

These values are analyzed by reducing their changes to the beginning of 2006 and by calculating increments over the previous year.

The correlation coefficient for each of these four variants is also calculated. Next formulas are applied:

$$
\begin{gathered}
r_{E 27, V B}=\frac{K_{E U 27, U K}}{\sigma_{E U 27 * \sigma_{U K}}} \\
K_{E U 27, U K}=\frac{\frac{1}{12} \sum_{i=1}^{12}\left(G D P_{E U 27}^{i}-\overline{G D P_{E U 27}}\right) *\left(G D P_{U K}^{i}-\overline{G D P_{U K}}\right)}{\sigma_{E U 27 * \sigma_{U K}}} \\
\sigma_{E U 27}=\frac{1}{11} \sum_{i=1}^{12}\left(G D P_{E U 27}^{i}-\overline{G D P_{E U 27}}\right) \\
\sigma_{V B}=\frac{1}{11} \sum_{i=1}^{12}\left(G D P_{U K}^{i}-\overline{G D P_{U K}}\right)
\end{gathered}
$$

wherein:

$G D P_{E U 27}^{i}$ - average GDP for the 27 EU countries for each year in the period 2006-2017

$\overline{G D P_{E U 27}}$ - mean value of average GDP for $27 \mathrm{EU}$ countries in the period 2006-2017

$G D P_{U K}^{i} \quad$ - GDP for the UK for each year in the period 2006-2017

$\overline{G D P_{U K}} \quad$ - mean value of GDP for UK in the period 2006-2017

$\sigma_{E U 27}-$ standard deviation of average GDP for $27 \mathrm{EU}$ countries in the period 2006-2017 and

$\sigma_{U K} \quad-$ the standard deviation of the average GDP for the UK in the period 2006-2017.

Relation between total UK's GDP and average GDP of EU is calculated with next formula:

$$
T A_{i}=\frac{\text { Total } G D P_{U K}^{i}}{\text { Average } G D P_{E U 27}^{i}}
$$


Relation between total UK's GDP and total GDP of EU is calculated with next formula:

$$
T T_{i}=\frac{\text { Total GDP } P_{U K}^{i}}{\text { Total } G D P_{E U 27}^{i}}
$$

Relation between total UK's GDP and total GDP of EU, indexed to 2006. year is calculated with next formulas:

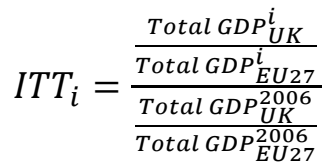

Indexing the values to 2006. year is used for clear comparison of UK's GDP share in GDP of EU27.

\section{Economic impacts of Brexit}

As a result of the definition for Brexit, it appears that economic losses make the biggest concern among other countries when analyzing the impact of Brexit. Statistics highlight the dominant position of the UK as an economic actor. The UK accounts for $14.8 \%$ of the EU's economic area, $12.5 \%$ of its population and accounts for $19.4 \%$ of EU exports (not counting intra-EU trade), but the UK has a trade deficit within the EU, which can be quite significant, De Ville and Orbie (2014).

The volume of trade between the UK and the EU is significant, with a large surplus for the benefit of the EU. EU27 exports to the UK an amount to 306 billion euros, and imports an amount to 184 billion euros (for reference 2015) according to De Grauwe (2016). As a comparison, trade statistics between the EU28 and the US have a similar size. In 2015, the EU exported 371 billion euros to the United States and imported 250 billion dollars of goods, Amadeo (2017). The difference in the volume of trade between the UK and the member states of the EU and the UK and the United States is only about $20 \%$, Busch and Matthes (2016).

The achieved exports and imports between the UK and the EU, in both directions expressed in billion euros and in percentage terms relative to GDP for the analyzed 2015 year, are shown in Table 1 and GDP percentages in Chart 1. 
Stevović M.: Economic impacts of Brexit to EU27 and UK

Table 1. Import, exports and total trade between the UK and EU27

\begin{tabular}{|c|c|c|c|c|c|c|}
\hline & $\begin{array}{c}\text { Import } \\
(€ \text { bn })\end{array}$ & $\begin{array}{c}\text { \% GDP } \\
\text { Import }\end{array}$ & $\begin{array}{c}\text { Export } \\
(€ \text { bn })\end{array}$ & $\begin{array}{c}\text { \% GDP } \\
\text { Export }\end{array}$ & $\begin{array}{c}\text { Trade } \\
(€ \text { bn })\end{array}$ & $\begin{array}{c}\% \text { GDP } \\
\text { Total trade }\end{array}$ \\
\hline EU27 & 184 & 1.5 & 306 & 2.5 & 491 & 4 \\
\hline UK & 306 & 11.9 & 184 & 7.1 & 491 & 19.1 \\
\hline
\end{tabular}

Source: Eurostat database (http://ec.europa.eu/eurostat)

Chart 1. Import, export and total trade in \% of GDP between EU27 and UK

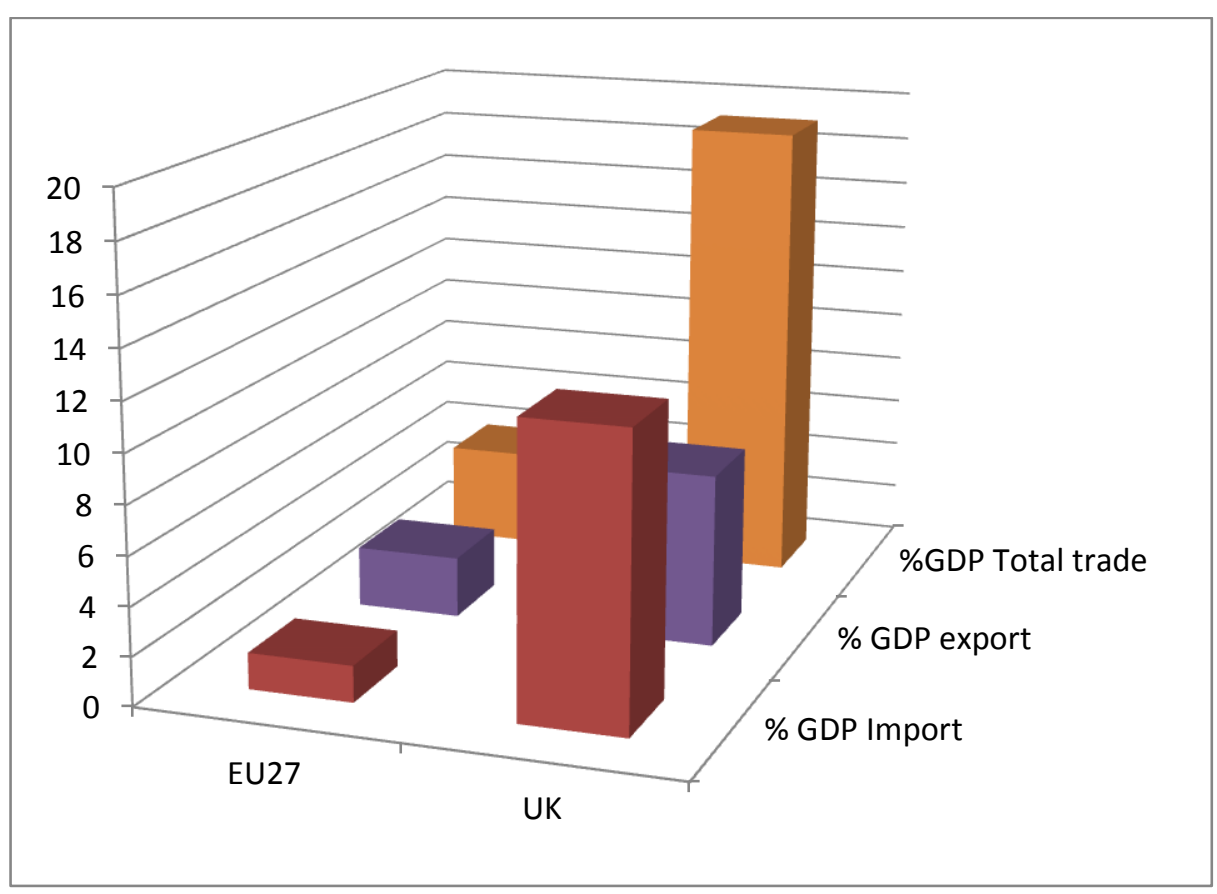

Source: Eurostat database (http://ec.europa.eu/eurostat)

\section{Analysis of trade with individual Member States}

Obviously, EU27 trade statistics with the UK vary by country, which represents a significant share of trade for certain countries and almost none for others, anticipating economic challenges some countries will face after Brexit. 
Germany is the largest exporter in the UK (68 billion euros), followed by the Netherlands (34 billion euros), France (28 billion euros), Belgium (23 billion euros), Italy (18 billion euros), Spain (16 billion euros) and Ireland (14 billion euros), Somai (2017).

All other Member States export less than 10 billion euros. The picture is roughly in line with the size of the economies in the EU27, except for the close neighbours of Great Britain, the Netherlands, Belgium and Ireland, which are more than proportionately represented, Whyman and Petrescu (2017b).

Similar is the situation when analyzing imports. Germany is in the leading position (34 billion euros), followed by France (20 billion euros), the Netherlands (19 billion euros), Ireland (19 billion euros) and Belgium (13 billion euros), Whyman and Petrescu (2017a).

Perhaps the most explicit statistics regarding the potential economic impact, which follows the Brexit, is the percentage of GDP attributed to exports and imports. More precisely, EU exports to the UK total $2.5 \%$ of total EU GDP, while exports from the UK to the EU27 account for much more than $7.5 \%$ of British GDP, Blake (2017).

Numbers become more indicative, showing possible future losses for UK, when viewed from the perspective of imports, since the UK imports from the EU account for $11.9 \%$ of UK GDP, while EU imports from the UK account for only $1.5 \%$ of EU GDP. So it is obvious that the general picture here is that the UK is much more dependent on the EU27 economically, but not vice versa, Burdekin, Hughson, and Gu (2018).

Previous statistics have only a limited value as a whole because different Member States have different levels of economic ties with Great Britain. Some Member States, especially smaller countries, are much dependent on the British market due to the nature of their economic activities.

The EU Member States whose exports to the UK account for the bulk of their GDP are Ireland (6.9\% of Ireland's GDP), Belgium (6.8\% of Belgium's GDP) and the Netherlands (6.3\% of the Netherlands's GDP). This means that these three countries will be most exposed to the forthcoming economic effects of Brexit, while most other member states are in the range of 1.5 to $3 \%$ of their own GDP, Emerson, Busse, Di Salvo, Gros, and Pelkmans (2017).

Another noteworthy trend is that most EU-27 countries have imports of goods and services from the UK at about $1 \%$ of their GDP, but several EU-27 Member States, such as Ireland, Malta, Cyprus, the Netherlands and Belgium - have imports that represent a significantly higher share and it is at the level of $9 \%$ of their GDP, Zuleeg (2018). 
Stevović M.: Economic impacts of Brexit to EU27 and UK

\section{EU27 export/import with the UK for all goods}

The following tables and diagrams provide an overview of exports and imports between all EU27 countries and the UK for all goods, ranked by the share of their own GDP in 2015.

Table 2 - Trade turnover and share in GDP for the UK and all EU27 countries

\begin{tabular}{|l|c|c|c|c|c|c|}
\hline & $\begin{array}{c}\text { EU27 imports from } \\
\text { the UK } € \text { bn) }\end{array}$ & $\%$ GDP & $\begin{array}{c}\text { EU27 exports to } \\
\text { the UK (€ bn) }\end{array}$ & $\%$ GDP & $\begin{array}{c}\text { Trade in } \\
\text { total }(€ \text { bn) })\end{array}$ & $\%$ GDP \\
\hline Ireland & 23 & 9 & 17 & 6.8 & 40 & 15.8 \\
\hline Belgium & 16 & 3.9 & 28 & 6.9 & 44 & 10.8 \\
\hline Netherlands & 24 & 3.5 & 43 & 6.3 & 67 & 9.9 \\
\hline Malta & 1 & 5.9 & 0 & 2.9 & 1 & 8.7 \\
\hline Czech Rep. & 3 & 1.6 & 3 & 3.2 & 5 & 4.8 \\
\hline Hungary & 2 & 1.6 & 3 & 3.2 & 5 & 4.8 \\
\hline Slovakia & 1 & 0.8 & 3 & 3.5 & 3 & 4.3 \\
\hline Germany & 42 & 1.4 & 85 & 2.8 & 127 & 4.2 \\
\hline Cyprus & 1 & 2.9 & 0 & 1.2 & 1 & 4.1 \\
\hline Latvia & 0 & 1.2 & 1 & 2.7 & 1 & 3.9 \\
\hline Lithuania & 0 & 1 & 1 & 2.9 & 1 & 3.9 \\
\hline Poland & 5 & 1.2 & 11 & 2.6 & 16 & 3.8 \\
\hline Sweden & 6 & 1.4 & 9 & 2.1 & 15 & 3.5 \\
\hline Denmark & 3 & 1.2 & 5 & 1.8 & 8 & 3.0 \\
\hline Spain & 12 & 1.1 & 19 & 1.8 & 32 & 2.9 \\
\hline Estonia & 0 & 1.5 & 0 & 1.3 & 1 & 2.8 \\
\hline Portugal & 2 & 1 & 3 & 1.8 & 5 & 2.8 \\
\hline France & 25 & 1.1 & 35 & 1.6 & 59 & 2.7 \\
\hline Finland & 2 & 0.9 & 3 & 1.4 & 5 & 2.2 \\
\hline Romania & 1 & 0.8 & 2 & 1.3 & 3 & 2.2 \\
\hline Bulgaria & 0 & 1.1 & 1 & 1.1 & 1 & 2.2 \\
\hline Italy & 12 & 0.7 & 23 & 1.4 & 34 & 2.1 \\
\hline Luxembourg & 0 & 0.6 & 1 & 1.3 & 1 & 1.9 \\
\hline Austria & 2 & 0.7 & 4 & 1.2 & 6 & 1.9 \\
\hline Slovenia & 0 & 0.7 & 0 & 1.2 & 1 & 1.9 \\
\hline Greece & 1 & 0.7 & 1 & 0.6 & 2 & 1.3 \\
\hline Croatia & 0 & 0.4 & 0 & 0.3 & 0 & 0.7 \\
\hline EU27 & 184 & 1.5 & 306 & 2.5 & 491 & 4.0 \\
\hline Sa & & & & & \\
\hline
\end{tabular}

Source: Eurostat database (http://ec.europa.eu/eurostat) 


\section{Modelling the economic future}

In order to assess the economic impact of Brexit on the EU27, it is necessary to analyze the possible results of negotiations that began on 19 June 2017. Furthermore, it should be noted that non-economic impacts of Brexit, especially political, are also correlated with negotiations, as if the UK achieves favourable economic/trade consequences for itself, other Member States can interpret that the EU can abandon itself in a relatively "painless" way, which could already be encouraged by existing disintegration forces.

As already mentioned, there is a whole range of possible outcomes of the negotiations, as well as their potential impact on the economy, in particular the economy of the UK and those EU27 countries that have intense trade relations with the UK.

Possible economic impacts were modeled by various leading scientific and political analysts and experts, and these studies were reviewed and applied by the Directorate-General for Internal Affairs of the European Parliament in a document entitled "An Assessment of the economic impact of Brexit on the EU27", which was actually a study that was drafted by the Committee for Internal Market and Consumer Protection, referred to herein as Emerson et al. (2017), by the name of the main author.

Chart 2. Overview of the EU27 trade with the UK expressed in percentage of GDP, detailed for import (red), export (blue) and total trade (light brown)

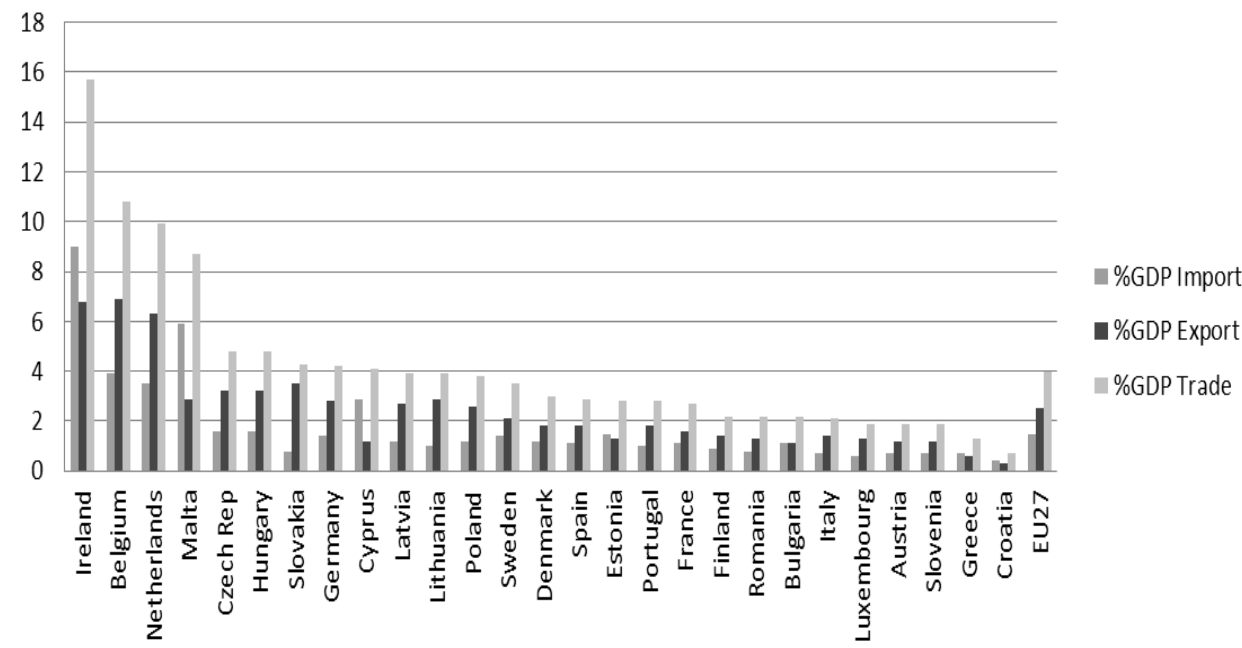

Source: Eurostat database (http://ec.europa.eu/eurostat) 
Chart 3 shows exports from individual EU27 countries to the UK and imports from the UK in Euros.

Chart 3. Exports and imports from individual EU27countries in relation to the UK

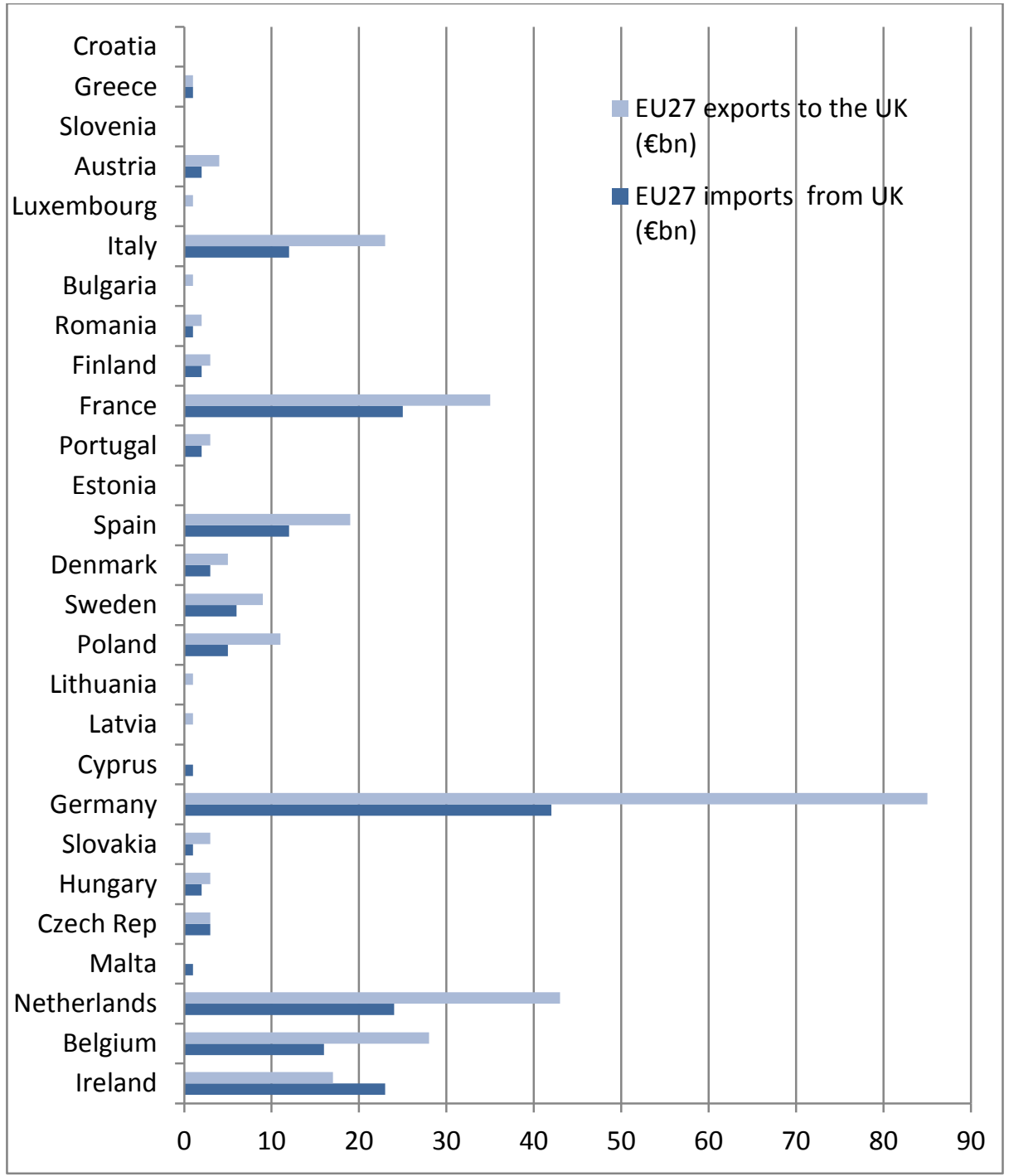

Source: Eurostat database (http://ec.europa.eu/eurostat) 
In general, the Internal Market and Consumers Protection (IMCO) study examined different scenarios of the UK Secession. It was found that the losses of the EU27 would be insignificant, although there could be more serious impacts on some Member States and on certain sectors. On the other hand, losses for the UK are calculated and projected as significant.

The study as a toehold for further analyzes of the forecast of Brexit adopted the starting point defined by Prime Minister (PM) Theresa May. In particular, her use of the term "strategic partnership" in the description of possible future relations of the UK with the EU pays the attention.

This describes the relationship the EU has with "countries of the world that are considered to be the most important for the EU for economic and/or political reasons, including the United States, Canada, Mexico, China, Japan and others that are not listed here. World economic powers take place at annual or two-year summit meetings, where they are directed to the global and discussed on bilateral issues. Some of the arrangements include preferential trade arrangements, but others do not.

From everything previously discussed and analyzed, the position and attitude of PM Theresa May emerged that the UK needs and wants "maximum access" to the single EU market, while retaining independence and not being part of it. Consequently to this defined goal, the UK begins withdrawal negotiations as fully favoured by the EU's single market for goods and services. However, the UK will certainly want to withdraw from certain areas. In this case, they will lose preferential treatment for the products and services in question.

For example, the UK may lose access to the procurement market, but strengthen its role in technical standards directives. However, as concluded in the IMCO study, the EU is considering its unified market law as a homogeneous whole, whilethe EU's agreement with Canada (CETA) ignoring the EU law.

The established models include Deep and Comprehensive Free Trade Agreement (DCFTA), an EU-Ukraine agreement offering a high level of access to the market, an European Economic Area (EEA) agreement, which also offers a high level of access to the market, and then the World Trade Organization (WTO), which does not imply any preferential access to the market.

\section{EU model agreements with other countries}

A concise overview of possible models of trade agreements and their estimated impacts on the EU and the UK is presented in Table 3. 
Stevović M.: Economic impacts of Brexit to EU27 and UK

Table 3. A series of scenarios and associated estimates of possible outcomes

\begin{tabular}{|l|l|}
\hline Scenario & Assessment \\
\hline 1. EEA & $\begin{array}{l}\text { Similar to the current state, too close to the } \\
\text { UK }\end{array}$ \\
\hline 1. 1 EEA + customs union & $\begin{array}{l}\text { Theoretical case, very close to present } \\
\text { state, too close to the UK }\end{array}$ \\
\hline 2. WTO & $\begin{array}{l}\text { Significant reduction in market access, a } \\
\text { loss for the UK }\end{array}$ \\
\hline 2.1 + aggressive competition & $\begin{array}{l}\text { With tax and regulatory tenders that are not } \\
\text { cooperative }\end{array}$ \\
\hline 3. Preferential models & $\begin{array}{l}\text { Possible, but the UK wants a } \\
\text { "Comprehensive Free Trade Agreement" }\end{array}$ \\
\hline 3.1 Simple free trade agreement & $\begin{array}{l}\text { More than a simple free trade agreement, } \\
\text { but the UK does not want a customs union }\end{array}$ \\
\hline $\begin{array}{c}\text { 3.2 Customs union (with a free trade } \\
\text { agreement) }\end{array}$ & $\begin{array}{l}\text { Selective and flexible in the past, but not } \\
\text { available for the UK }\end{array}$ \\
\hline $\begin{array}{l}\text { 3.3 Swiss model } \\
\text { 3.4 The Comprehensive Economic and Trade } \\
\text { Agreement (CETA) (Canada) }\end{array}$ & $\begin{array}{l}\text { Comprehensive, beyond a simple free trade } \\
\text { agreement; no content of the EU acquis }\end{array}$ \\
\hline 3.5 DCFTA (Ukraine) & $\begin{array}{l}\text { Deeply and comprehensively, with a lot of } \\
\text { EU acquis content }\end{array}$ \\
\hline $\begin{array}{c}\text { 3.6 Stabilization and Association Agreement } \\
\text { (SAA) (Balkan) }\end{array}$ & $\begin{array}{l}\text { Worse than DCFTA, for accession of } \\
\text { membership candidates, but not for the UK }\end{array}$ \\
\hline $\begin{array}{l}\text { 3.7 Partnership and Cooperation Agreement } \\
\text { (PCA) (Kazakhstan) }\end{array}$ & $\begin{array}{l}\text { Little more than the WTO, not available for } \\
\text { the UK }\end{array}$ \\
\hline 3.8 Strategic partnership & $\begin{array}{l}\text { Global diplomacy at the level of strategic } \\
\text { partnership summit }\end{array}$ \\
\hline $\begin{array}{l}\text { 3.9 Idem with the goal of CFTA } \\
\text { agreement, Somewhere between CETA and } \\
\text { DCFTA }\end{array}$ \\
\hline
\end{tabular}

Source: Emerson et al. (2017)

Probable point of conflict, cause of tensions in the negotiations, will be "freedom of movement" against "market access" and the idea that the UK will have to pay market access, which means it should make a significant contribution to the EU budget, Emerson et al. (2017).

Regarding prediction of probable outcomes, several attempts have been made in the literature to determine the influence of Brexit using the state of the art techniques of trade policy modelling. By grouping different combinations of parameters and potential impacts, three models were derived from official sources (The Organisation for Economic Cooperation and Development - OECD, the UK Treasury and Dutch Central Planning Bureau), while three were from academic or expert institutions: London School of Economics (LSE), Institut IFO in Munich, Open Europe in London).

Although no model can absolutely and simultaneously simulate all economic effects of Brexit - it is important to point out that most of the experts, if not all, inaccurately expected even more severe consequences for the UK economy models "provide a cluster of findings that are close to consensus in terms of relative impact size", Emerson et al. (2017) Because the UK trade with the EU27 
represents a significantly higher share of GDP in the country than EU participation in GDP (this comparison is not quite equal, since it compares the GDP of a country (the UK) with GDP of 27 state trade block), it can therefore be concluded that the economic impacts of Brexit will be more negative for the UK than for the EU block.

The IMCO study Emerson et al. (2017) is characterized by the assumptions in analyzing the possible consequences of Brexit as optimistic and pessimistic. "Optimistic" - implies that only a slight increase in trade barriers is assumed. "Pessimistic" - implies that there will be more trade barriers between the participating countries. There are also "central" scenarios that avoid the above extremes.

For example, the optimistic scenario assumes that the UK uses the trade regime used by Norway, which is located in the EEA. According to the experts assessments and analyzes, observing the views of PM May, this scenario is too optimistic. The pessimistic scenario, on the other hand, reflects the worst scenario. According to it, the UK would be forced to use the WTO trade rules. Such a scenario of further develoentdevelopment of trade relations is called "Hard Brexit". When assessing the impact of these trade regimes, models focus on impact assessments through quantitative GDP analyzes Lawless and Morgenroth (2016).

In the literature Emerson et al. (2017) and Lawless and Morgenroth (2016), a decline of $30 \%$ of EU27 exports to the UK and a fall of $22 \%$ of the UK exports to the EU27 was calculated. These statistics, which rely on applying the most favourable WTO tariffs, result in a decline of $2 \%$ of total EU27 exports to the rest of the world. Given the significantly higher exposure of Ireland and Belgium, the two countries are facing a direct reduction in exports of $4 \%$ and $3.1 \%$. The impact of Brexit on total exports from the UK is considerably higher and according to one study, it is $9.8 \%$, while the decline in exports to the EU27 would be $3 \%$ in the WTO scenario and $1.7 \%$ in the assumption of the FTA model. the UK would face a $21.8 \%$ reduction in total exports under the assumptions of the WTO scenario and $12.5 \%$, assuming the adopted FTA model in Table 3, McGowan (2018)

\section{Statistical analyses and correlations}

Estimation of the brexit impact on the economic parameters of the EU and UK is conducted, based on the statistical data on GDP for the period $2006-2017$ (Table 4). The UK's GDP share in the GDP of EU27 (total EU's GDP decreased by UK's GDP) and the dependence of the GDP changes of these two economies (UK economy and the EU27 economy) are analyzed as a dinamic function over time. 
Stevović M.: Economic impacts of Brexit to EU27 and UK

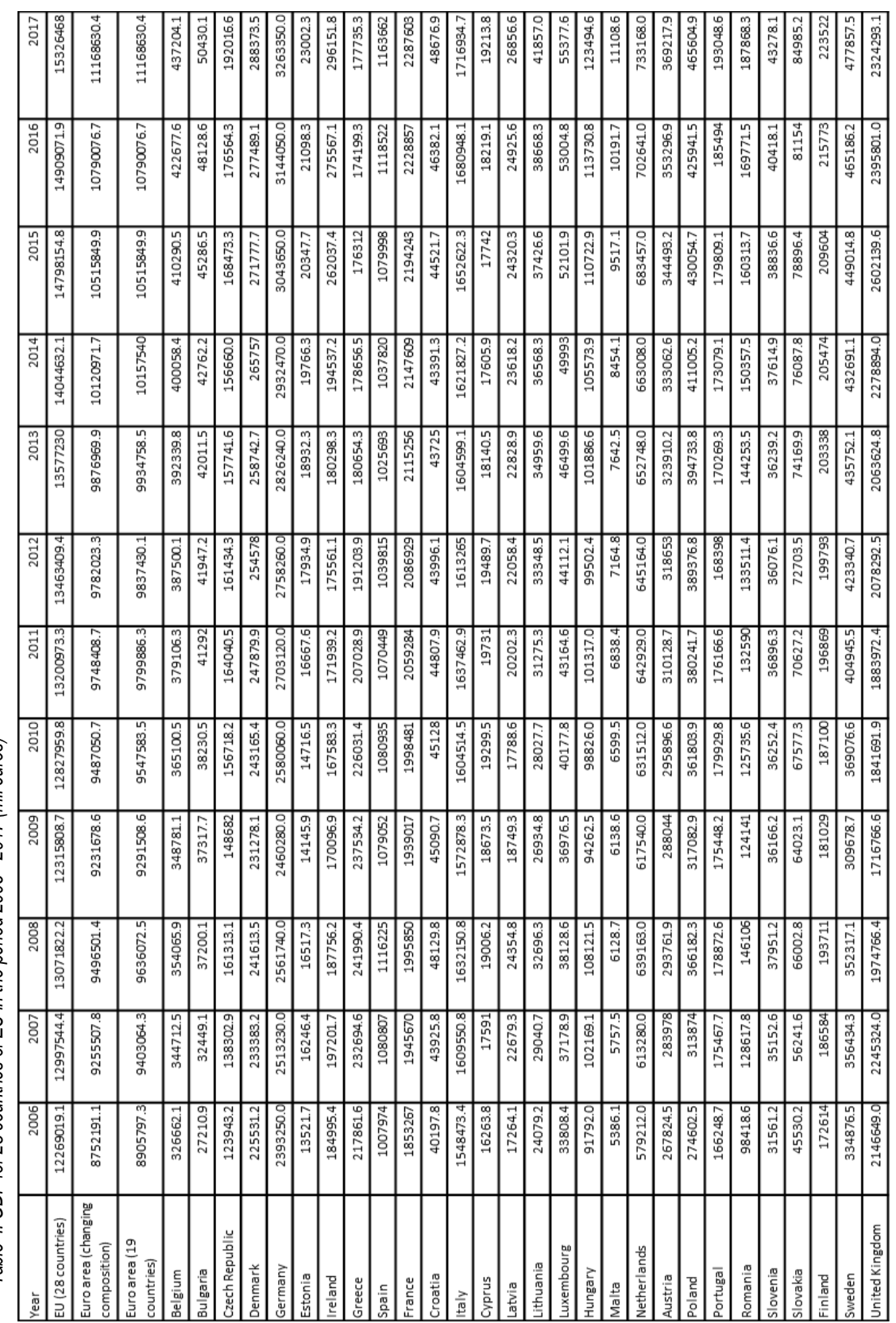


Chart 4. Growth of average EU GDP with and without UK versus 2006

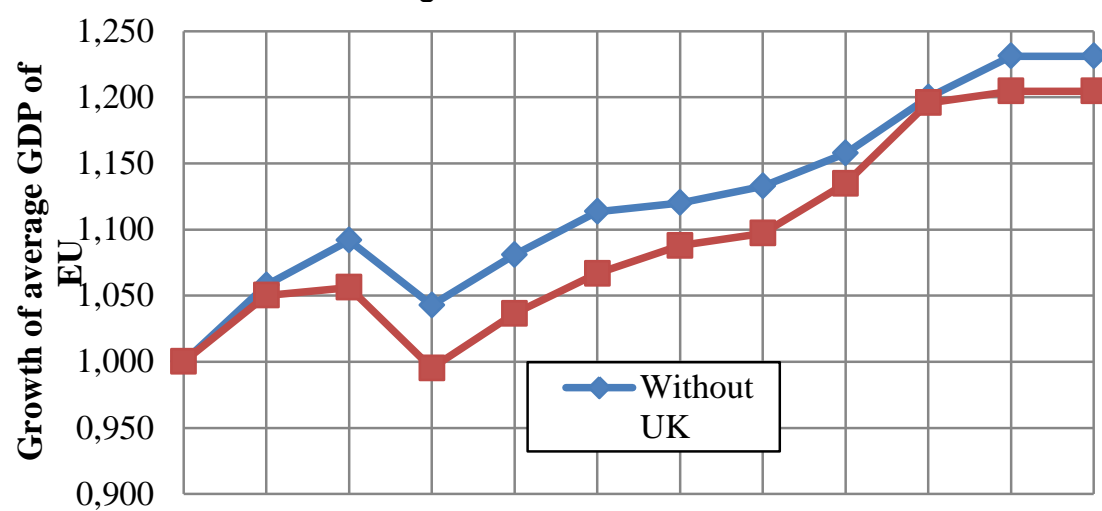

200620072008200920102011201220132014201520162017

Source: author calculation

Based on this chart, it can be concluded that the growth in the average GDP in the EU27 is higher without the UK, than with GDP of UK. This phenomenon can be explained by the accelerated development of individual members with a lower base for growth, that have benefited from their development potential by entering and using benefits in the EU. Growth of total GDP of the EU, with and without UK, compared to 2006 is presented on the Chart 5.

Chart 5. Growth of total GDP of the EU, with and without UK, compared to 2006

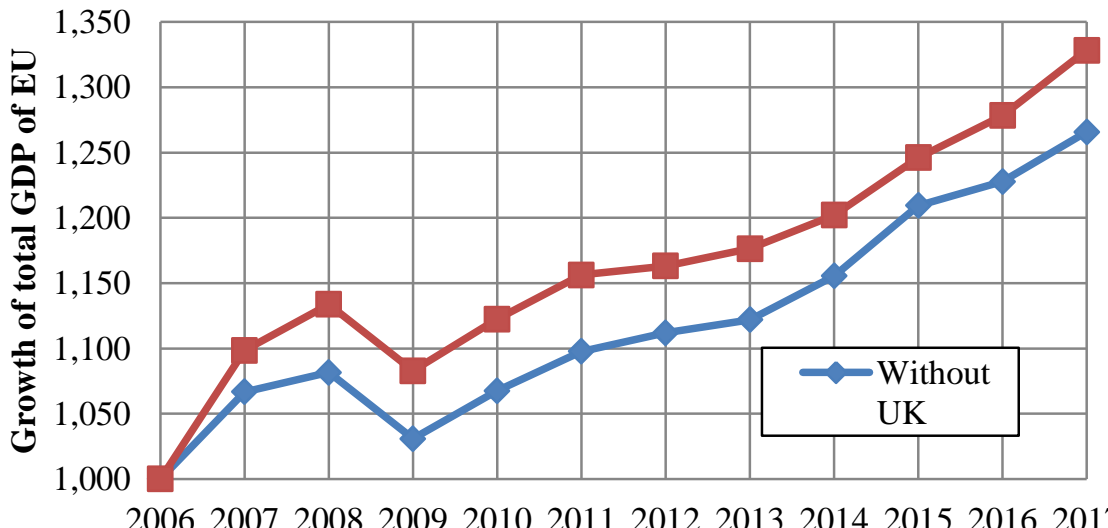

Source: author calculation

Increased growth in total GDP of the EU with the UK in relation to growth without UK can be explained by the fact that the UK has a significant share in the total GDP of the EU27 so that it significantly contributes to the increase in 
the EU's total GDP. Growth of the average GDP of the EU with and without VB in relation to the previous year is presented on Chart 6.

Chart 6 - Growth of the average GDP of the EU with and without VB in relation to the previous year

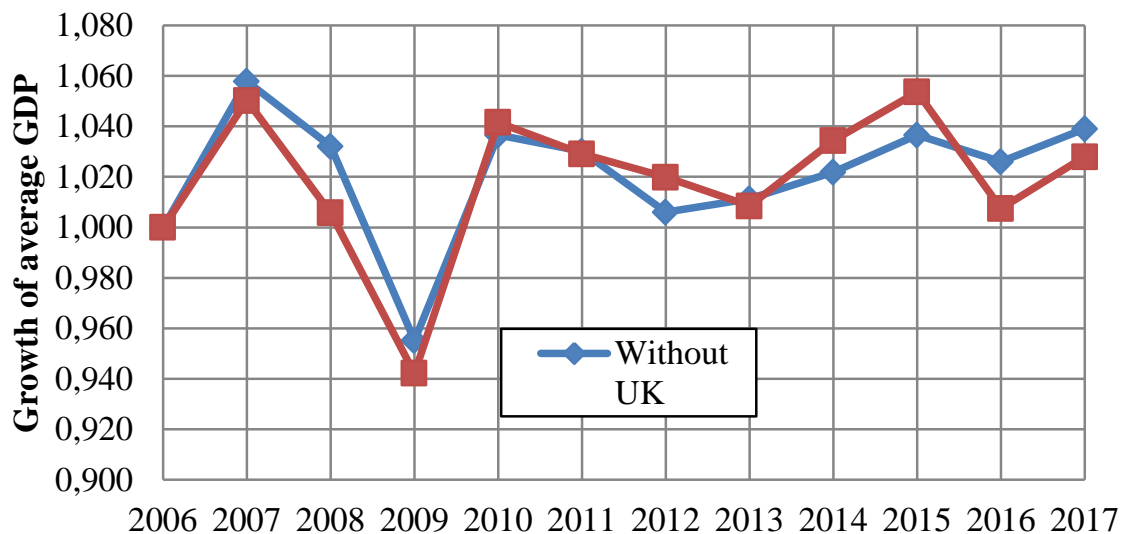

Source: author calculation

Growth of the average GDP in the EU is higher than UK GDP growth (measured year by year) in the period 2006-2009 and 2016-2017, while in other periods it is lower. This means that the decline in UK GDP adversely affect the average EU27 GDP, while UK GDP growth does not stimulate growth of the average GDP in the EU27 to the same extent. Growth of total GDP of the EU with and without UK compared to the previous year is presented on Chart 7.

Chart 7 - Growth of total GDP of the EU with and without UK compared to the previous year

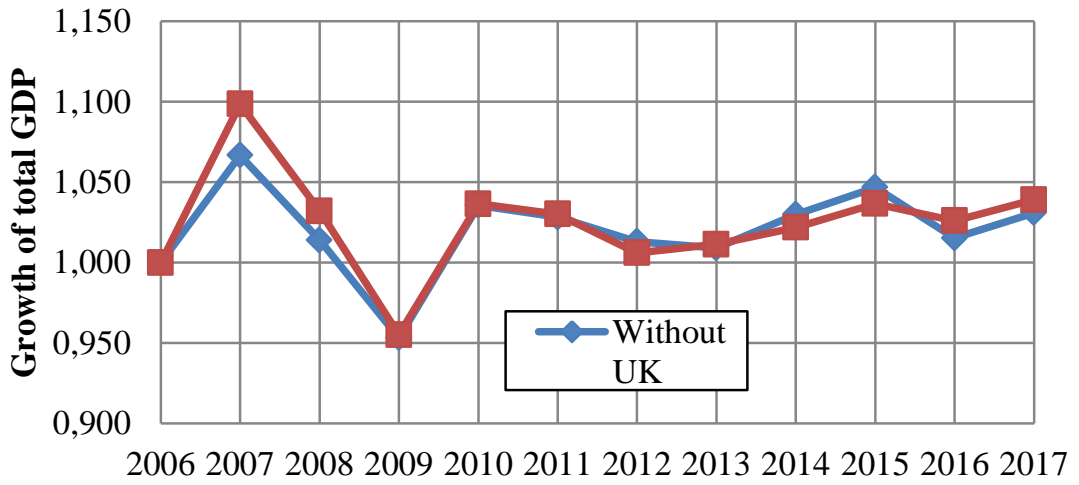

Source: author calculation 
Analyzing at the growth of the EU's total GDP with and without UK in relation to the previous year, it can be concluded that growth with UK is higher, except for the years 2012, 2014 and 2015. This means that GDP growth in the UK influences GDP growth in the EU27. Share of UK's total GDP in the total GDP of EU27 is presented on Chart 8.

Chart 8. Share of UK's total GDP in the total GDP of EU27

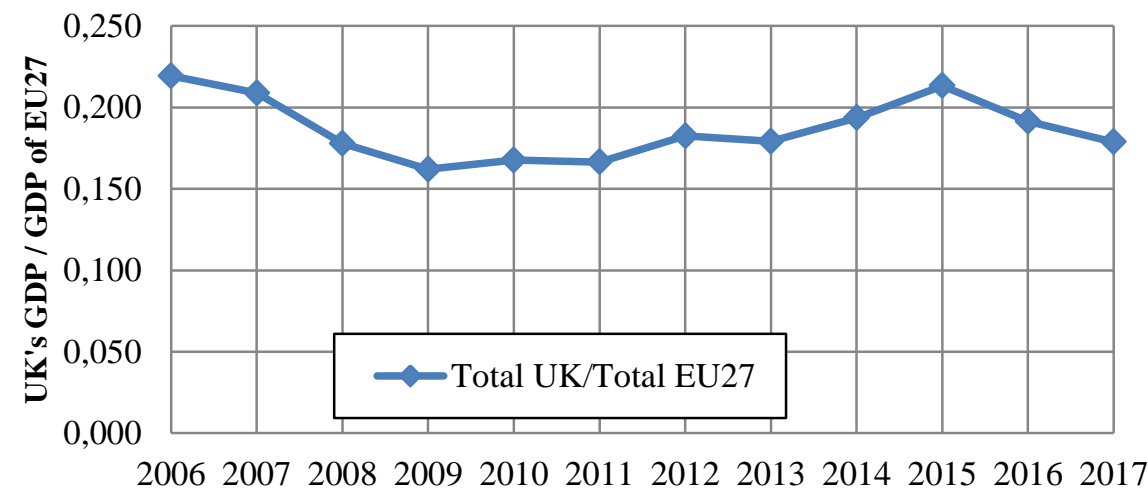

Source: author calculation

It is obvious that the share of UK's total GDP in the total GDP of EU27 is taking values between $16 \%$ and $22 \%$ in the period $2006-2017$. Share of UK's total GDP in the total GDP of EU27 is in decreasement from $22 \%$ to $18 \%$. The ratio of total UK's GDP and the GDP of EU27 indicates that changes have been in favour of the EU27 in all ages, ie. that the overall EU27 economy has grown faster than the overall UK economy. Ratio of the UK's total GDP and the average GDP of the EU27 is presented on Chart 9.

Chart 9. Ratio between the total GDP of the UK and the average GDP of the EU27

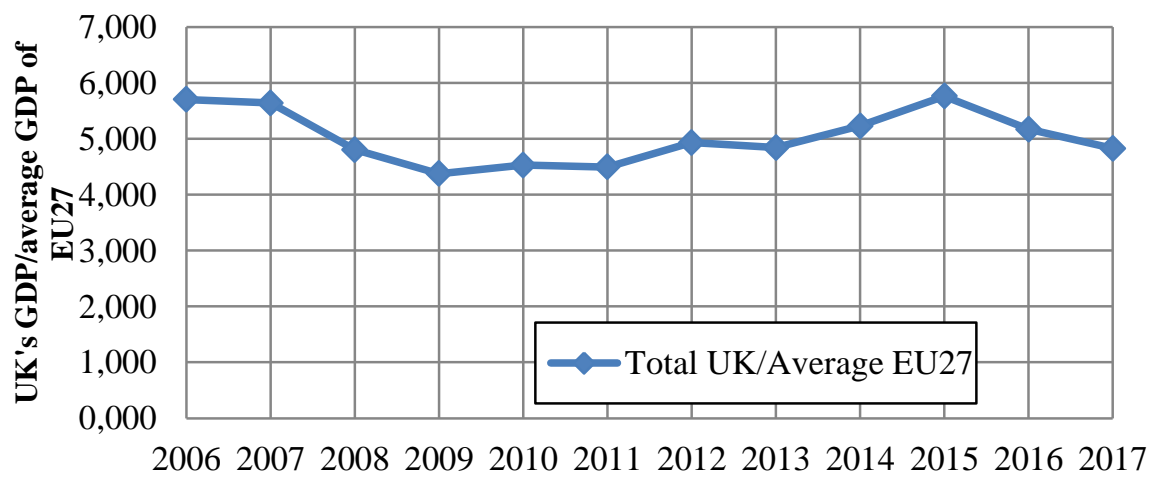

Source: author calculation 
Analizyng the chart 9 , it can be concluded that total GDP of the UK is 4.4 to 5.8 times higher than the average GDP of the EU27. Based on the comparison of the GDP of the UK and the average GDP of the EU27, it can also be concluded that it has been in the decline since 2006. This is a result of the higher growth of the average GDP of the EU27 in relation to GDP UK. The changes were in favor of the EU27, except in 2015, when this ratio exceeded the 2006 value. Ratio between the UK's total GDP and the total GDP of EU27, indexed to 2006. is presented on Chart 10.

Chart 10 - Ratio between the total GDP of the UK and the total GDP of the EU27 indexed to 2006.

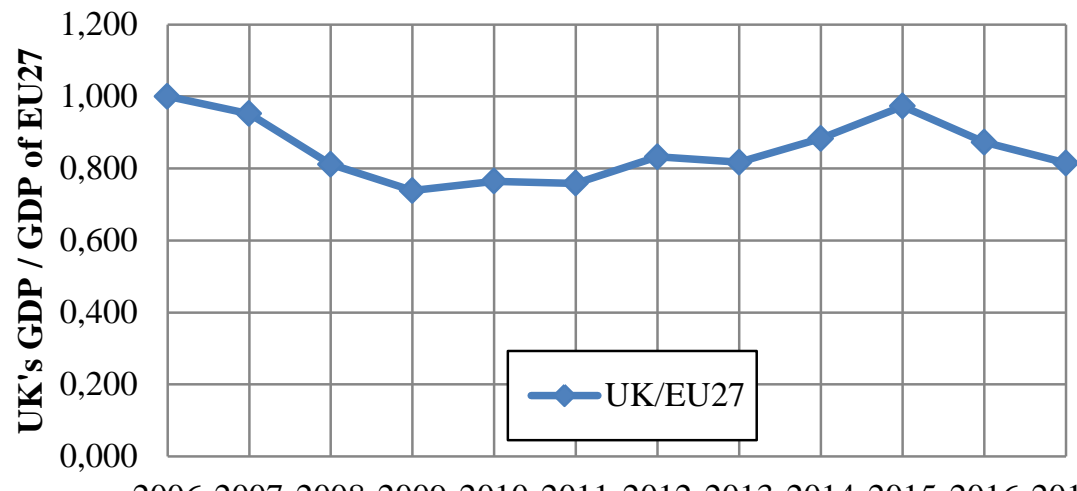

200620072008200920102011201220132014201520162017

Source: author calculation

It is clear from the chart 10 that the index of participation UK's total GDP in total GDP of EU27 is decreased for $20 \%$ in the analyzed period of time 2006 2017. The participation of the UK economy in the EU27 economy was with certain variation, but constantly less than the initial participation in 2006 .

Based on all correlation functions calculated for the period from 2006 to 2017. year and statistical analyses conducted, it is possible to conclude the following:

- From the point of view of global economic trends, the resilience of the average GDP of the EU27 to negative economic trends is higher without UK than with the UK. It is particularly indicative in 2009 year (after the global economic crisis), when the fall in the average GDP without the UK was lower than with the UK, while the decline of GDP in the UK was higher than the decline in the EU27's GDP;

- Growth of average EU27 GDP in relation to the previous year is higher without VB than with the UK in the higher number of years of the observed 
period (2006-2017). It is also indicative that the total GDP of EU27 is equal with and without UK in 2009. Also, the fall in the overall EU27 GDP without GDP of UK in this year is lower than the fall in GDP together with the UK.

- Viewed from the angle of UK, in the period from 2006 to 2017, UK had a growth index of GDP share in average GDP of the EU27 less than 1 (the value reduced to 2006), which means that the growth rate of the GDP of the UK was lower than the growth rate of average EU27 GDP.

As a result of the disaggregation it can be concluded that each party will try to keep positive effects for itself from the split in terms of GDP: EU27 will maintain its resistance to negative economic trends, while the UK will use more of the chance in the global market without any restriction from the EU.

The studies of causal connection of this phenomenon require significant additional researches, but the overall result can be interpreted as greater benefits for the EU27 from the UK than vice versa. The economic impact of Brexit can be calculated, but it ultimately depends on the type of agreement that the UK and EU27 negotiate as per Article 50. That is why a different possible scenarios are developped in the literature.

\section{Summary of impact on GDP after the Brexit}

Recapitulation of possible impacts of Brexit on the decline in GDP, ranging from 0.11 to $0.52 \%$ for the EU27, cumulatively for the period up to 2030 , as well as the decline in GDP in the UK for the range of optimistic and pessimistic scenarios, expressed in \% and billions of euros, according to a review of various expert sources from different literature, is shown in Table 6. Taking into account the average value, which assumes that the change is incremental, the average effect on annual GDP would be from $0.01 \%$ to $0.05 \%$, Alexander, Barnard, Ferran, Lang, and Moloney (2018). On the other hand, it should be noted that the Booth/Open Europe model differs much from others because the model uses a radically "optimistic" scenario, or rather a more liberal formula that would allow the UK to establish free trade unilaterally with both, the EU and the rest of the world. There were three such cases: in Singapore, Georgia and Hong Kong.

The two studies Rojas-Romagosa (2016) and Ramiah, Pham, and Moosa (2017) provide a comprehensive overview for each of the 27 countries. From the perspective of Member States, studies show that, as expected, those countries that are most dependent on trade in the UK, whether due to proximity or for cultural reasons, are most exposed, and therefore can expect the greatest impact in terms of GDP decline. In addition to the UK itself, in which the biggest changes will occur due to the EU exit, Ireland will, within the framework of the WTO option, record a loss of GDP of slightly over $3.5 \%$, and 
in the scenarios of the FTA (Roja) will have a GDP decline of $3.5 \%$, while Belgium will have losses of $2 \%$ within the WTO and $1.5 \%$ in the framework of the free trade agreement, followed by the Netherlands (with losses of just over $1 \%$ of the WTO option and slightly below $1 \%$ in the FTA), followed by Portugal and Spain, below $1 \%$. These data are all about the loss of GDP by 2030, and as mentioned earlier, the number is significantly lower when calculating the annual average.

However, according to the IMCO study, GDP losses do not show the whole picture. Malta and Cyprus, as well as Luxembourg, are among the most heavily loaded countries, according to the study "Felbermair" in the larger, and "Rojo" to a lesser extent due to the expected decline in financial services trade with the UK. These items represent a huge proportion to the GDP of these economies. While Belgium and the Netherlands have distinctly visible changes, the numbers can be interpreted as prone to unjustified large losses because a good portion of the transit between the UK and the EU27 is carried through the seaports of Belgium and the Netherlands without adding value.

As in analyzed studies in Table 6, the Global Council Impact Study in the literature Counsel (2015) divides the EU Member States according to the criteria of exposure to those that have:

1. "high exposure", followed by

2. "significant exposure", then

3. " niche exposure" and

4. "low exposure".

As in other studies, Ireland, the Netherlands and Cyprus are categorized as having high exposure, followed by Denmark, the Czech Republic, Belgium, the Baltic states, Slovakia and Spain, which have significant exposure, while other members are listed as niche exposure or low exposure.

At the sectoral level, pessimistic scenarios show an impact that is much sharper than the average; this is true for the auto industry, where the "most favoured nations" tariff plan would apply. Also, abandoning the UK from the Customs Union could negatively affect complex multiple supply chains, which would lead to a significant loss of demand for cars Mini, Range Rovers, Nissan and Toyota that are "made in the UK". But if the depreciation of the pound continues, it can serve to counter this force, achieving an adequate level of competition De Vries (2017).

\section{Influence of Brexit on financial industry}

In the period before the vote for Brexit, the financial sector and financial services were the main domains feared to hit London city by the size of 
damage and level of disruption in those areas. The reason was justified, since it was later confirmed that there is a general consensus that the financial services sector will suffer the most, and that certain segments of financial services will be severely affected by others. In addition, financial services directly provide 1.2 million jobs and account for $7.9 \%$ of GDP in the UK, according to Counsel (2015).

Although the London financial sector has established competitive advantages, which cannot be nearly eliminated, EU regulations will make it difficult for London to serve the EU's financial markets, in particular for trade in euro and trade in financial products. The UK has run euro banknotes, but the eurozone countries want to see this activity run in Eurozone, and that the European Central Bank is overseeing it, which is likely to happen after Brexit, as Britain will no longer be protected by the Rule of Single Market of the European Court of Justice, Alexander et al. (2018).

The Peterson Institute recently held a symposium to present a survey on the impact Brexit has on financial services. In the literature Djankov (2017), a study describing the immediate effects that Brexit is expected to have on the financial sector is presented as follows:

1. Decrease in income from $12-18 \%$ in London city

2. Drop in employment by $7-8 \%$

Djankov stressed that financial services can be divided into four broad sectors:

1. banking,

2. insurance (and reinsurance),

3. asset management and

4. clearing services.

The effects of Brexit will not be distributed equally in all four sectors. As part of his analysis, Djankov wrote: "The qualitative and quantitative data for the year 2016 were analyzed for each of these four sectors, and then the operations were reviewed in each of these sectors, and the revenues coming from the servicing of the EU countries is $23 \%$ of total EU production. In insurance, $15 \%$ of exports go to the EU, but only a small part of this sector will be hit because the insurance sector has shifted business and occupied positions in other EU countries, thus avoiding the issue of EU licenses, Odermatt (2018).

Djankov wrote that "clearing" services would be most affected by the "passport requirement" in "clearing" operations. Djankov further showed that financial services have first-class effects and second-order effects, such as legal services. Many second-class companies will be forced to close the business and move to another location, to another state. 
Stevović M.: Economic impacts of Brexit to EU27 and UK

Table 6. An overview of Brexit implications on UK and EU27 GDP, for different scenarios

\begin{tabular}{|c|c|c|c|c|}
\hline Scenario & EU27 & & UK & \\
\hline & $(\%)$ & $(€$ Bill) & $(\%)$ & $(€$ Bill) \\
\hline Ottaviano / LSE & & & & \\
\hline Optimistic: UK similar to EEA / Switzerland & $-0,12$ & $-14,5$ & $-1,28$ & $-33,0$ \\
\hline Pessimistic: UK as a third country, WTO & $-0,29$ & $-35,1$ & $-2,61$ & $-67,3$ \\
\hline Aichele / Felbermair / Institut IFO & & & & \\
\hline Optimistic: UK similar to EEA / Switzerland & $-0,1$ & $-12,1$ & $-0,64$ & $-16,5$ \\
\hline Pessimistic: UK as a third country, WTO & $-0,3$ & $-36,3$ & $-2,3$ & $-59,3$ \\
\hline OECD & & & & \\
\hline $\begin{array}{c}\text { Optimistic: Foreign direct investment (FDI), trade, } \\
\text { migration, small declines }\end{array}$ & - & - & $-2,7$ & $-69,7$ \\
\hline Central: idem medium decline & - & - & $-5,1$ & $-131,6$ \\
\hline Pessimistic: idem big declines & $-0,8^{*}$ & $-96,9$ & $-7,7$ & $-198,7$ \\
\hline Roja-Romagosa / Centralli Planning Bureau, NL & & & & \\
\hline $\begin{array}{l}\text { Optimistic: Free trade agreements (FTA) after } 10 \\
\text { years with half of the NTB between EU and } \\
\text { the WTO }\end{array}$ & $-0,6$ & $-72,7$ & $-3,4$ & $-87,7$ \\
\hline Pessimistic: UK as a third country, WTO & $-0,8$ & $-96,9$ & $-4,1$ & $-105,8$ \\
\hline Booth / Open Europe & & & & \\
\hline $\begin{array}{l}\text { Optimistic: UK unilateral free trade agreement with } \\
\text { world, plus ambitious deregulation agenda }\end{array}$ & the whole & & $+1,5$ & 38.7 \\
\hline Pessimistic: UK as a third country, WTO & $-0,34$ & $-41,2$ & $-2,2$ & $-56,8$ \\
\hline UK Treasury & & & & \\
\hline Optimistic: UK similar to EEA & & & $-3,8$ & $-98,0$ \\
\hline $\begin{array}{l}\text { Central: UK in a customs union such as Turkey or } \\
\text { Canadian CETA }\end{array}$ & & & $-6,2$ & $-160,0$ \\
\hline Pessimistic: UK as a third country, WTO & & & $-7,5$ & $-193,5$ \\
\hline Average & & & & \\
\hline Optimistic & $-0,11$ & $-13,3$ & $-1,31$ & $-33,8$ \\
\hline Pessimistic & $-0,52$ & $-63,0$ & $-4,21$ & $-108,6$ \\
\hline
\end{tabular}

Source: Emerson et al., 2016

In literature Djankov (2017), Nicolas Veron predicted that the best option for some London financiers would be to move to locations in the EU and that the best positioned secondary financial centers could benefit if they moved to Frankfurt, Amsterdam, Dublin, Luxembourg and less to Paris. According to analyzes Anderson and Wilson (2017), London would remain dominant, but not as dominant as it was before Brexit. London's position as an international financial centre could be jeopardized if a large number of European firms migrate after Brexit.

At the same time, Brexit can change the balance in European legislation debates, as the UK is currently taking a stand to refuse any risk associated with the introduction of regulations. Brexit increase the index of economic policy uncertainty (EPU), as per Baker, Bloom, and Davis (2016). Some regulatory initiatives, which the UK successfully blocked, could be accepted 
without the influence of the UK on such issues. In the coming years, the EU's financial regulatory environment could change.

\section{Conclusion}

This paper presents the economic aspect of Brexit, i.e. the relationship between the economies of the UK and 27 EU countries. The analysis of the relationship between these economies served as a basis for concluding the economic aspect of the separation process. There will be changes in economic relations between both sides after the separation process.

Based on the results of the performed analysis, followed by the literature review, there are no reasons for not accepting the initial hypothesis:

- The first initial hypothesis can be accepted because undoubtedly there will be a difficult exchange between both sides of negotiation Whatever model of disruption will be adopted ("Norwegian", "Swiss" or the exit from the unique EU market), it will have negative consequences on the UK economy because it will be difficult to access the EU market or the UK will have to make economic concessions. Although the EU as a whole will have fewer negative consequences than disagreement over the World Bank, they will not be equally distributed across all EU27 countries. There will be more affected countries whose exports to UK have a greater share in the national GDP and

- The second initial hypothesis can be also accepted because on the basis of statements coming to the public, there is a tendency for each side to protect their interests.

Extensive economic analysis suggests that Brexit's initial logic is that UK is in the interest of maximizing its economic benefits (because it has made a decision on disintegration and thus has shown that more economic benefits will be left than leaving the EU) and that the EU should fight to minimize the damage (since she was not the initiator of the withdrawal, which would mean that her disagreement was not in the economic interest) was inconsistent with the results of the economic analysis. This result also suggests that the European Union, from an economic point of view, has a better negotiating position.

\section{References}

Alexander, K., Barnard, C., Ferran, E., Lang, A., \& Moloney, N. (2018). Brexit and Financial Services: Law and Policy. Bloomsbury Publishing.

Amadeo, K. (2017). What Is Monetary Policy. Objectives, Types and Tools. 
Anderson, B., \& Wilson, H. F. (2017). Everyday Brexits. Area.

Baker, S. R., Bloom, N., \& Davis, S. J. (2016). Measuring economic policy uncertainty. The Quarterly Journal of Economics, 131(4), 1593-1636.

Blake, D. (2017). Brexit and the City. City University of London - Cass Business School. manuscript, web.

Burdekin, R.C.K., Hughson, E., \& Gu, J. (2018). A first look at Brexit and global equity markets. Applied Economics Letters, 25(2), 136-140. doi:10.1080/13504851.2017.1302057

Busch, B., \& Matthes, J. (2016). Brexit-the economic impact: A meta-analysis: IWReport.

Castro, F.G., Kellison, J.G., Boyd, S.J., \& Kopak, A. (2010). A Methodology for Conducting Integrative Mixed Methods Research and Data Analyses. Journal of Mixed Methods Research, 4(4), 342-360. doi:10.1177/1558689810382916

Counsel, G. (2015). Brexit: The impact on the UK and the EU. Pozyskano z: https://www. global-counsel.

co. uk/sites/default/files/special-reports/downloads/Global\% 20Counsel Impact of Brexit. pdf..

De, G.P. (2016). What Future for the EU After Brexit. Intereconomics, 51(5), 249-251. doi:10.1007/s10272-016-0612-0

De, V.F., \& Orbie, J. (2014). The European Commission's Neoliberal Trade Discourse since the Crisis: Legitimizing Continuity through Subtle Discursive Change. The British Journal of Politics and International Relations, 16(1), 149-167. doi:10.1111/1467-856x.12022

De Vries, C. E. (2017). Benchmarking Brexit: How the British decision to leave shapes EU public opinion. JCMS: Journal of Common Market Studies, 55, 38-53.

Djankov, S. (2017). The City of London after Brexit.

Emerson, M., Busse, M., Di, S.M., Gros, D., \& Pelkmans, J. (2017). An Assessment of the Economic Impact of Brexit on the EU27. 22 March 2017.

Lawless, M., \& Morgenroth, E. (2016). The Product and Sector Level impact of a hard Brexit across the EU. ESRI, WP(550).

McGowan, L., \& McGowan, L. (2017). Planning Brexit, July 2016-March 2017. In Preparing for Brexit. (pp. 33-48). Cham: Springer Nature. doi:10.1007/978-3319-64260-4_3

Odermatt, J. (2018). Brexit and British Trade Policy Routledge Handbook of the Politics of Brexit. Routledge.

Ramiah, V., Pham, H. N., \& Moosa, I. (2017). The sectoral effects of Brexit on the British economy: early evidence from the reaction of the stock market. Applied Economics, 49(26), 2508-2514.

Rojas-Romagosa, H. (2016). Trade effects of Brexit for the Netherlands. CPB background document.

Sarkar, D. (2007). Lean for service organizations and offices: A holistic approach for achieving operational excellence and improvements. ASQ Quality Press.

Somai, M. (2017). Brexit: Risks And Opportunities Of Disintegration. Unia Europejska, 1. PI, 243(2), 9..

Stevovic, M., \& Crnobrnja, M. (2015). Security policy of the European Union and refuge crisis. Megatrend revija, 12(3), 329-342. doi:10.5937/megrev1503329s

Stevović, M. (2018a). Brexit challenges and prospective political effects on the EU countries and UK, Proceedings of the International Scientific Conference "LAW 
Stevović M.: Economic impacts of Brexit to EU27 and UK

2018 - Current Problems of Law and Legal Science", Belgrade, May 2018, 374-395.

Stevović, M. (2018b). Impact of Brexit to security and key areas in the EU and UK, Account and Financial Management Journal, Vol 3, Issue 01, January 2018, 1247-1253.

Whyman, P.B., \& Petrescu, A.I. (2017). The Economics of Brexit: A Cost-Benefit Analysis of the UK's Economic Relationship with the EU. Springer.

Whyman, P.B., Petrescu, A.I., Whyman, P.B., \& Petrescu, A.I. (2017). Foreign Direct Investment (FDI). In The Economics of Brexit. (pp. 123-161). Cham: Springer Nature. doi:10.1007/978-3-319-58283-2 4

Zuleeg, F. (2018). Reflections on the June European Council Summit. Policy. 26-27. 